\title{
Distinct prognostic values and antitumor effects of tumor growth factor $\beta 1$ and its receptors in gastric cancer
}

\author{
FENGPING LIU ${ }^{1}$, HONGWEI WANG ${ }^{1}$ and MEI ZHANG ${ }^{2}$ \\ ${ }^{1}$ Operation Room and ${ }^{2}$ Department of Radiotherapy Technology, Linyi Lanshan Cancer Hospital, \\ Linyi, Shandong 276002, P.R. China
}

Received November 27, 2018; Accepted November 26, 2019

DOI: 10.3892/ol.2020.11849

\begin{abstract}
Gastric cancer (GC) is one of the most common malignancies and is the second leading cause of cancer-associated mortality world-wide. In the present study, the prognostic value and antitumor effects of transforming growth factor $\beta 1$ (TGF $\beta 1$ ) and its receptors in GC were explored. The online Kaplan-Meier plotter database was used to investigate the prognostic values of TGF $\beta 1$ and its receptors. The present study demonstrated that low mRNA expression levels of TGF $\beta 1$ and its 3 receptors, transforming growth factor $\beta 1$ (TGF $\beta$ R1), TGF $\beta R 2$ and TGF $\beta R 3$, was associated with improved overall survival time in patients with GC. Cell Counting Kit-8 and Transwell assays were used to confirm the effects of TGF $\beta 1$, TGF $\beta R 1$, TGF $\beta R 2$ and TGF $\beta R 3$ on the proliferation, migration and invasiveness of the AGS and MKN45 GC cell lines. It was found that the knockdown of these genes blocked cell proliferation, migration and invasion in GC cells. To the best of our knowledge, the present study is the first to determine the role of TGF $\beta R 1$ and TGF $\beta R 3$ in GC cells. The results indicate that in addition to TGF $\beta 1$ and TGF $\beta$ R2, TGF $\beta$ R1 also plays a specific role in the occurrence and development of tumors. Thus, these markers may be considered as potential prognostic indicators in human GC. The findings of the present study indicate that not only TGF $\beta 1$ and TGF $\beta$ R2, but also TGF $\beta$ R 1 is involved in the progression of GC. The findings of the present study provide new ideas and approaches for the treatment of patients with GC.
\end{abstract}

\section{Introduction}

Gastric cancer (GC) is one of the most common malignancies with $\sim 1$ million new cases reported globally every year according to the GLOBOCAN (2002) and Cancer Incidence

Correspondence to: Dr Mei Zhang, Department of Radiotherapy Technology, Linyi Lanshan Cancer Hospital, 6 Lingyuan East Street, Linyi, Shandong 276002, P.R. China

E-mail: 1335493492@qq.com

Key words: prognosis, gastric cancer, transforming growth factor $\beta 1$, transforming growth factor $\beta$ receptor in Five Continents databases (1). The mortality rate of GC is the second highest amongst all malignant tumors (2). A good prognosis in patients with GC requires a timely diagnosis and is also associated with different pathological characteristics, genetic background and the treatment method used $(3,4)$. Due to developments in cellular and molecular biology, understanding of the pathogenesis of GC has gradually increased over the past 20 years, but the overall survival rate of patients remains unchanged (5). Tumor related molecules, signaling pathways, proteases and their inhibitors are all involved in the process of tumor development $(6,7)$. Therefore, the molecular analysis of these processes has important significance in the development of therapeutics and the prognosis of GC in clinical practice $(8,9)$.

Transforming growth factor $\beta 1$ (TGF $\beta 1$ ) is a type of polypeptide cytokine with multiple functions in humans (10). Almost all cells in the body can produce TGF $\beta 1$ and its receptors, including epithelial, endothelial, hematopoietic, nerve and connective tissue cells (11). Assoian et al successfully extracted TGF $\beta 1$ from human platelets for the first time in $1983(8,12)$. TGF $\beta 1$ has since been reported to play an important role in the regulation of cellular proliferation (12). TGF $\beta$ receptors (TGF $\beta$ R) are high affinity binding proteins of TGF $\beta 1$ located on the cell membrane (13). These receptors have been categorized into 3 isoforms according to electrophoretic mobility; TGF $\beta$ R1, TGF $\beta R 2$ and TGF $\beta R 3$ (14). By binding to TGF $\beta R$, TGF $\beta 1$ exerts a wide range of biological effects (14). Previous studies have focused on the relationship of TGF $\beta 1$ and TGF $\beta$ Rs with cancer $(14,15)$. TGF $\beta 1$ demonstrates diverse functions in tumors, such as the inhibition of cell proliferation, differentiation and apoptosis in the early stages of tumor development (14). In advanced stage cancer, TGF $\beta$ promotes angiogenesis, induction of extracellular matrix production, invasion and metastasis $(16,17)$. TGF $\beta 1$ and TGF $\beta$ R are important members of the TGF/SMAD signaling pathway, which is involved in the regulation of cell proliferation and differentiation. The TGF $\beta / S M A D$ pathway is one of the most frequently altered signaling pathways in tumors, including GC (18-20).

The online Kaplan-Meier plotter (K-M plotter) is capable of assessing the effect of any gene or gene combination on survival in breast, ovarian, lung and gastric cancer, using patient samples on gene chips or RNA-seq data (21). To date, the K-M plotter has been used to identify and validate 
a number of genes in these cancer types (22-27). The K-M plotter database contains the prognostic and mRNA mapping information of 876 patients with GC (21). In the present study, the K-M plotter was used to determine the prognostic value of mRNA expression of TGF $\beta 1$ and its receptors in patients with GC, and the effects of TGF $\beta 1$ were validated in GC cell lines.

\section{Materials and methods}

Prognostic analyses of patients with GC. Using the K-M plotter (kmplot.com/analysis/) the association between the mRNA expression of TGF $\beta 1$ and its receptors, and overall survival (OS) time was analyzed. Using the K-M plotter online software, gene expression, relapse free and OS time data can be downloaded from the Gene Expression Omnibus (Affymetrix microarrays only), the European Genome-Phenome Archive and The Cancer Genome Atlas databases (kmplot.com/analysis/index.php? $\mathrm{p}=$ service \&cancer $=$ gastric). Clinical data were collected from 876 patients with GC, including sex, perforation history, Tumor Node Metastasis (TNM) stage (28), Lauren classification (29), HER2 status, pathological grade and treatment method. The mRNA expression levels of TGF $\beta 1$ and its receptors were entered into the database, and Kaplan-Meier survival curves were generated for the OS time of patients with GC. The patients were split into low- and high-expression groups according to the expression levels of TGF $\beta 1$ and its receptors with auto select best cutoff. The log rank P-value and the hazard ratio (HR) with a $95 \%$ confidence interval (CI) was calculated.

Cell culture and transfection. The AGS and MKN45 human gastric cancer cell lines were purchased from the Cell Bank of the Chinese Academy of Sciences. Cells were cultured in DMEM supplemented with $10 \%$ fetal bovine serum, $100 \mathrm{U} / \mathrm{ml}$ penicillin and $0.1 \mathrm{mg} / \mathrm{ml}$ streptomycin, and incubated in a $5 \% \mathrm{CO}_{2}$ incubator at $37^{\circ} \mathrm{C}$ for $48 \mathrm{~h}$. Cells in the exponential growth phase were harvested and transfected with TGF $\beta 1$, TGF $\beta$ R1, TGF $\beta$ R2- or TGF $\beta$ R3-specific siRNA (3 $\mu \mathrm{g})$ using Lipofectamine ${ }^{\circledR} 2000$ (Thermo Fisher Scientific, Inc) according to the manufacturer's protocol. The cells were incubated for $48 \mathrm{~h}$ prior to further experimentation. Following siRNAs were used (Ruibo; ribobio.com/): TGF $\beta 1$, 5'-GCCCATCTAGGT TATTTCCGTGG-3'; TGF $\beta$ R1, 5'-AGGGTACTACGTTGA AAGACTTA-3'; TGF $\beta R 2$, 5'-ACGATAATGTTTGGTAGT ATTCA-3'; TGF $\beta R 3$, 5'-AACTTAAGATAGCAAGAAATA TC-3'; negative control siRNA (a scrambled siRNA control, siC) 5'-UUCUCCGAACGUGUCACGUTT-3'. Untreated AGS and MKN45 cells were used as the blank control, and cells treated with the scrambled siRNA control were used as the negative control.

Cell Counting Kit-8 (CCK-8) assay. After transfection, cells $\left(1 \times 10^{3}\right.$ cells/well) were seeded into a 96 -well plate, cultured at $37^{\circ} \mathrm{C}$ in a $5 \% \mathrm{CO}_{2}$ incubator. The proliferation of cells was measured every $24 \mathrm{~h}$. Fresh DMEM containing $10 \mu \mathrm{l} \mathrm{CCK}-8$ solution (Beijing Solarbio Science \& Technology Co., Ltd.) was added to each well to detect cell proliferation according to the manufacturer's protocol. After incubation for $2 \mathrm{~h}$ at $37^{\circ} \mathrm{C}$, cell proliferation was determined by measuring the optical density (OD) value at a wavelength of $450 \mathrm{~nm}$. The CCK-8 assay was performed in triplicate.

Transwell migration and invasion assays. Following transfection, cells $\left(1 \times 10^{3}\right.$ cells/well) in serum-free medium were seeded into the upper chambers of transwell inserts, while medium supplemented with $10 \%$ FBS was added into the lower chambers. After incubation for $48 \mathrm{~h}$, the cells that had migrated into the lower chamber were fixed with $4 \%$ paraformaldehyde for $15 \mathrm{~min}$ and stained with $0.1 \%$ crystal violet for $5 \mathrm{~min}$. Images were captured using a light microscope at X100 magnification. For the invasion assay, the upper chambers were coated with Matrigel prior at $37^{\circ} \mathrm{C}$ for $4 \mathrm{~h}$ to the addition of the cells.

Reverse transcription fluorescence quantitative $P C R$ $(R T q-P C R)$. An Ultrapure RNA kit (CWBio) was used of the extraction of total RNA form AGS and MKN45 cells after the transfection for $24 \mathrm{~h}$. A HiFiScript cDNA Synthesis kit (CWBio) was used for reverse transcription. The following thermocycling conditions were used for reverse transcription: Incubation at $42^{\circ} \mathrm{C}$ for $15 \mathrm{~min}$ and at $85^{\circ} \mathrm{C}$ for $5 \mathrm{~min}$. Then, qPCR was performed using MagicSYBR Mixture (CWBio). The following primers was used: TGF $\beta 1$ forward, 5'-CCCCTACATTTG GAGCCTGG-3' and reverse, 5'-GCACGATCATGTTGGACA GC-3'; TGF $\beta R 1$ forward, 5'-ACCGCACTGTCATTCACCAT-3' and reverse, 5'-CTGAGCCAGAACCTGACGTT-3'; TGFßR2 forward, 5'-GCTCTGGTGCTCTGGGAAAT-3' and reverse, 5'-CCAGCACTCAGTCAACGTCT-3'; TGFßR3 forward, 5'-GCCCTGATGAGCTCCTGTTT-3' and reverse, 5'-GGC ACAGCCTGACAAAACAG-3'; $\beta$-actin forward, 5'-CCCGAG CCGTGTTTCCT-3' and reverse, 5'-GTCCCAGTTGGTGAC GATGC-3'. The following thermocycling conditions were used for qPCR: Initial denaturation at $95^{\circ} \mathrm{C}$ for $30 \mathrm{sec} ; 95^{\circ} \mathrm{C}$ for $5 \mathrm{sec}$, $60^{\circ} \mathrm{C}$ for $30 \mathrm{sec}$, with a total of 40 cycles. The relative expression levels of genes were analyzed using $2^{-\Delta \Delta \mathrm{Cq}}$ method (30).

Western blotting. Total protein was extracted from the AGS and MKN45 cells after the transfection for $48 \mathrm{~h}$ using a RIPA lysis buffer (Beijing Solarbio Science \& Technology Co., Ltd.). Protein determination was detected using a BCA Protein Assay kit (CWBio). A total of $20 \mu \mathrm{g}$ protein of each group was loaded on a $10 \%$ gel, resolved using SDS-PAGE and subsequently transferred to a PVDF membrane. The membrane was blocked with $5 \%$ non-fat milk at room temperature for $1 \mathrm{~h}$. The protein was incubated with primary antibodies for at $4^{\circ} \mathrm{C}$ overnight and secondary antibodies at room temperature for $1 \mathrm{~h}$. The following antibodies were used in this research: Anti-TGF $\beta 1$ antibody (1:500; ab92486; Abcam), anti-TGF $\beta R 1$ antibody (1:500; ab31013; Abcam), anti-TGF $\beta R 2$ antibody (1:500; ab186838; Abcam), anti-TGF $\beta R 3$ antibody (1:200; ab97459; Abcam) and goat anti-rabbit secondary antibody (1:5000; ab6721; Abcam). An Enhanced ECL Chemiluminescent Substrate kit (Shanghai Maokang; maokangbio.com/index. action) was used for visualization. Protein level was analyzed using ImageJ version 1.41 (National Institutes of Health).

Statistical analysis. SPSS 20.0 (IBM Corp.) was used for the statistical analysis. All data in the present study are presented as the mean \pm SD. The data were analyzed from three separate experiments. Statistical significance was determined using 

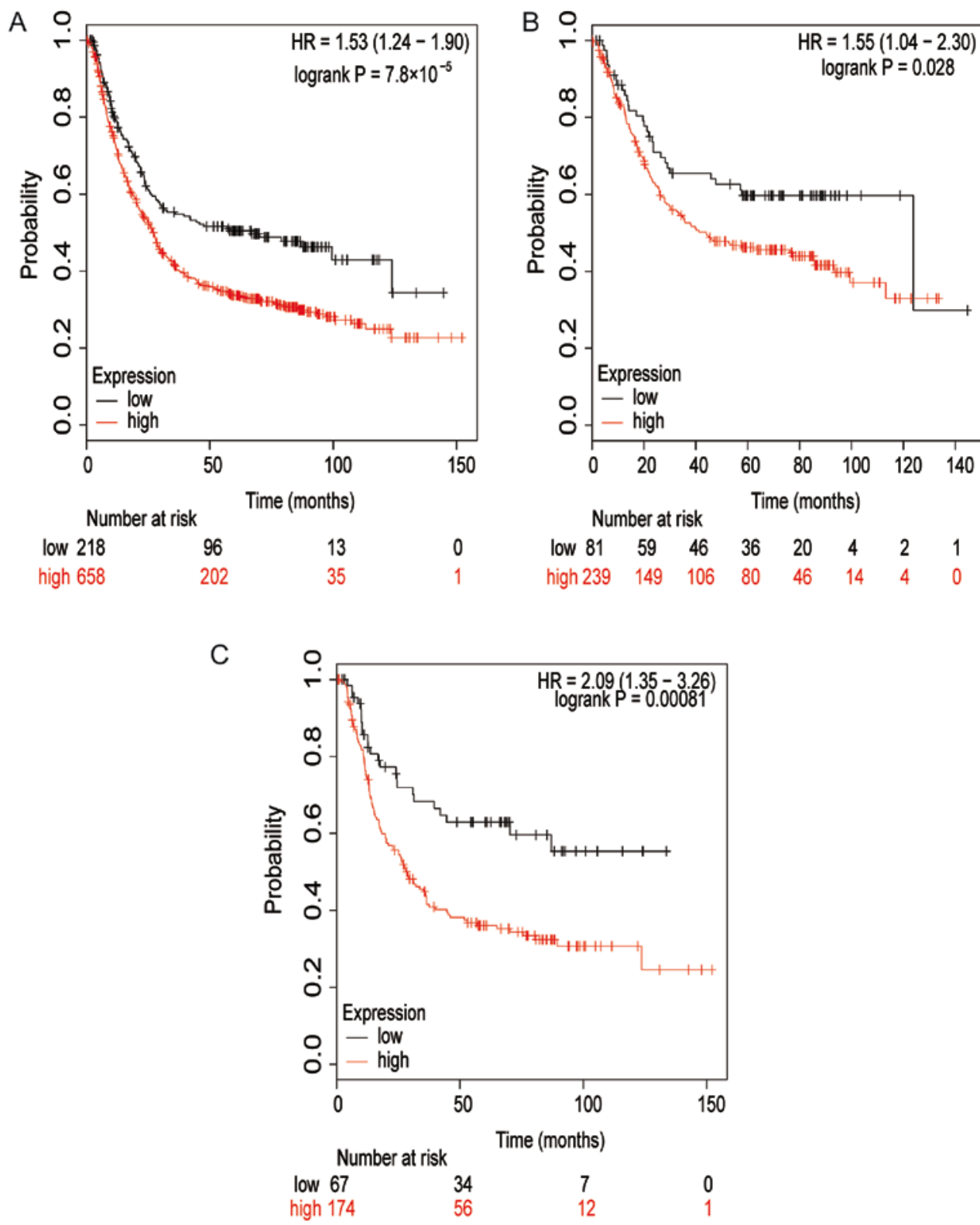

Figure 1. Determination of the prognostic value of TGF 31 mRNA expression using the K-M plotter online tool. The desired Affymetrix ID is valid: 203084_at (TGF $\beta 1)$. Survival curves representing overall survival times for (A) total patients with GC $(n=876)$, (B) patients with intestinal type GC ( $=320)$ and $(C)$ patients with diffuse type GC ( $\mathrm{n}=241)$. Patients were divided according to low- and high-TGF $\beta 1 \mathrm{mRNA}$ expression prior to survival curves being plotted. HR, hazard ratio; GC, gastric cancer; TGF $\beta 1$, transforming growth factor $\beta 1$.

one-way ANOVA followed by the Bonferroni's post-hoc test. $\mathrm{P}<0.05$ was considered to indicate a statistically significant difference.

\section{Results}

Low expression of TGF $\beta 1$ and its receptors is associated with improved prognosis in patients with $G C$. The prognostic values of the mRNA expression of TGF $\beta 1$ and its receptors was determined using the online K-M plotter tool. The Affymetrix IDs of TGF $\beta 1$, TGF $\beta R 1$, TGF $\beta$ R2 and TGF $\beta R 3$ are 203084_at, 206943_at, 207334_s_at and 204731_at respectively. Survival curves were generated for all patients with $\mathrm{GC}(\mathrm{n}=876)$, patients with intestinal type GC $(n=320)$ and patients with diffuse type GC $(n=241)$. In 876 cases, only the above patients have clear pathological classification information, therefore only these patient data were analyzed.

Firstly, the prognostic value of TGF $\beta 1$ mRNA expression was determined (Fig. 1). Low mRNA expression levels of TGF $\beta 1$ was associated with higher OS time and therefore, improved prognosis in patients with GC (HR, 1.53; 95\% CI, 1.24-1.90; P<0.0001; Fig. 1A). Low TGF $\beta 1$ mRNA expression was also observed to be associated with a higher OS time in patients with intestinal type GC (HR, 1.55; 95\% CI, 1.04-2.30; $\mathrm{P}=0.028$; Fig. 1B), and patients with diffuse type GC (HR, 2.09; 95\% CI, 1.35-3.26; $\mathrm{P}=0.00081$; Fig. 1C).

Next, the prognostic value of TGF $\beta R 1$ mRNA expression was analyzed. Low TGF $\beta$ R 1 mRNA expression in patients with $\mathrm{GC}$ was associated with higher OS time (HR, 1.54; 95\% CI, 1.30-1.83; P<0.0001; Fig. 2A). Low TGF $\beta R 1$ mRNA expression was also found to be associ- 

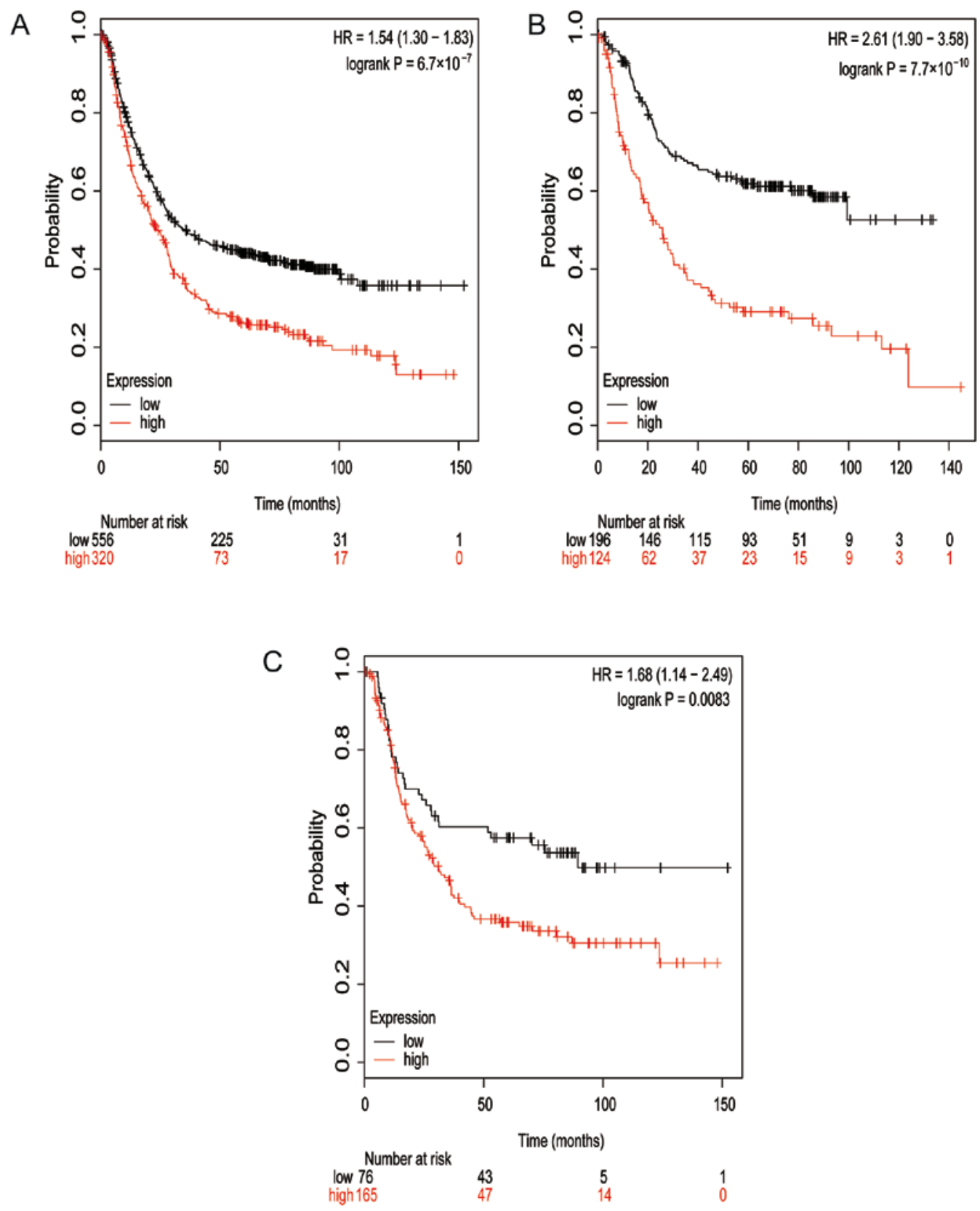

Figure 2. Determination of the prognostic value of TGFßR1 mRNA expression using the K-M plotter online tool. The desired Affymetrix ID is valid: 206943_at (TGFßR1). Survival curves representing overall survival times for (A) total patients with GC ( $\mathrm{n}=876)$, (B) patients with intestinal type GC ( $\mathrm{n}=320)$ and $(\mathrm{C})$ patients with diffuse type GC $(\mathrm{n}=241)$. Patients were divided according to low- and high-TGF $\beta 1 \mathrm{mRNA}$ expression prior to survival curves being plotted. HR, hazard ratio; GC, gastric cancer; TGFßR1, transforming growth factor receptor $\beta 1$.

ated with higher OS time in patients with intestinal type GC (HR, 2.61; 95\% CI, 1.90-3.58; P<0.0001; Fig. 2B) and patients with diffuse type GC (HR, 1.68; 95\% CI, 1.14-2.49; $\mathrm{P}=0.0083$; Fig. 2C).

The survival curves associated with TGF $\beta R 2$ mRNA expression are represented in Fig. 3. Low expression levels of TGF $\beta R 2$ mRNA were associated with an improved prognosis in patients with GC $(\mathrm{HR}, 1.25 ; 95 \% \mathrm{CI}, 1.05-1.49 ; \mathrm{P}=0.012$; Fig. 3A) and in patients with intestinal type $\mathrm{GC}(\mathrm{HR}=1.82$; 95\% CI, 1.32-2.50; $\mathrm{P}=0.012$; Fig. 3B). TGF $\beta \mathrm{R} 2$ was also associated with a modest improvement in the prognosis of patients with diffuse type GC; however, this increase was not statistically significant (HR, 1.33; 95\% CI, 0.94-1.89; $\mathrm{P}=0.11$; Fig. 3C).
The survival curves of TGF $\beta$ R 3 mRNA expression for all patient groups investigated are represented in Fig. 4. Low mRNA expression level of TGF $\beta$ R3 was associated with improved prognosis in patients with GC (HR, 1.22; 95\% CI, 1.03-1.45; $\mathrm{P}=0.021$; Fig. 4A). Low mRNA expression of TGF $\beta R 3$ was also associated with improved prognosis in patients with diffuse type GC (HR, 2.14; 95\% CI, 1.52-3.01; $\mathrm{P}<0.0001$; Fig. 4C). TGF $\beta \mathrm{R} 3$ was also associated with a modest improvement in the prognosis of patients with intestinal type GC; however, this increase was not statistically significant (HR, 1.33; 95\% CI, 0.92-1.91; P=0.13; Fig. 4B). According to the results of the present study, low mRNA expression levels of TGF $\beta 1$, TGF $\beta$ R1, TGF $\beta R 2$ and TGF $\beta R 3$ were all associated with a higher OS time in patients with GC. 

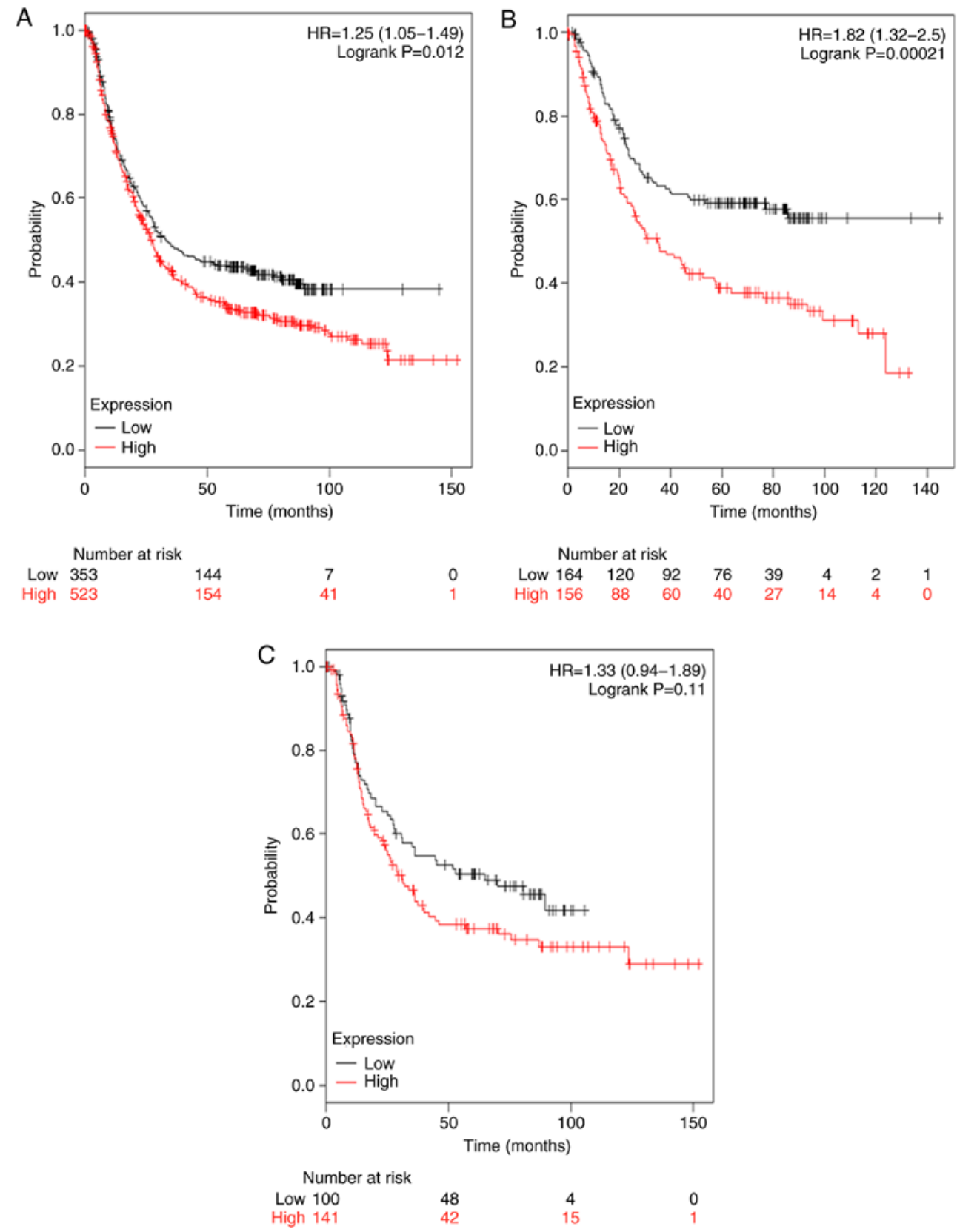

Figure 3. Determination of the prognostic value of TGFßR1 mRNA expression using the K-M plotter online tool. The desired Affymetrix IDs is valid: 207334_s_at (TGFßR2). Survival curves representing overall survival times for (A) total patients with GC (n=876), (B) patients with intestinal type GC $(\mathrm{n}=320)$ and $(\mathrm{C})$ patients with diffuse type $\mathrm{GC}(\mathrm{n}=241)$. Patients were divided according to low- and high-TGF $\beta 1 \mathrm{mRNA}$ expression prior to survival curves being plotted. HR, hazard ratio; GC, gastric cancer; TGF $\beta$ R2, transforming growth factor receptor $\beta 2$.

Furthermore, the association between TGF $\beta$ signaling and prognosis in patients with GC with different clinicopathological features, including clinical stages (Table I), HER2 status (Table II), pathological grades (Table III) and different treatment methods (Table IV) was analyzed. As presented in Table I, low TGF $\beta 1$ mRNA expression was associated with an improved prognosis at clinical stages 2 of GC (HR, 2.61; 95\% CI, 1.16-5.86; $\mathrm{P}=0.016)$. Low mRNA expression of TGF $\beta R 1$ was associated with a better prognosis at clinical stages 2 (HR, 3.39; 95\% CI, 1.86-6.61; P<0.0001; Table I) and 3 (HR, 1.9; 95\% CI, 1.42-2.55; $\mathrm{P}<0.0001$; Table I) in patients with GC. Low mRNA expression of TGFßR2 was also associated with a more favorable prognosis at clinical stages 1 (HR, 9.1; 95\% CI, 1.19-69.50; P=0.0099; Table I), 2 (HR,
2.32; 95\% CI, 1.27-4.25; P= 0.0051; Table I) and 4 (HR, 1.76; 95\% CI, 1.13-2.67; P= 0.012; Table I). Low mRNA expression of TGF $\beta$ R3 was also found to be associated with better prognosis in clinical stages 2 (HR, 2.79; 95\% CI, 1.53-5.08; $\mathrm{P}=0.00048$; Table I), 3 (HR, 1.36; 95\% CI, 1.02-1.8; $\mathrm{P}=0.035$; Table I) and 4 (HR, 2; 95\% CI, 1.33-3; P=0.00063; Table I) patients with GC.

Low mRNA expression levels of TGF $\beta 1$ (HR, 1.66; 95\% CI, 1.27-2.15; P=0.00014; Table II) and TGF $\beta$ R2 (HR, 1.33; 95\% CI, 1.05-1.67; P=0.016; Table II) were associated with a better prognosis in HER2 patients with GC. Low mRNA expression of TGFßR1 [(HER2: HR, 1.67; 95\% CI; 1.33-2.09; P<0.0001; Table II) (HER2 ${ }^{+}$: HR, $1.48 ; 95 \% \mathrm{CI}$, 1.14-1.92; P=0.0028; Table II)] and TGF $\beta$ R3 [(HER2: HR, 
A

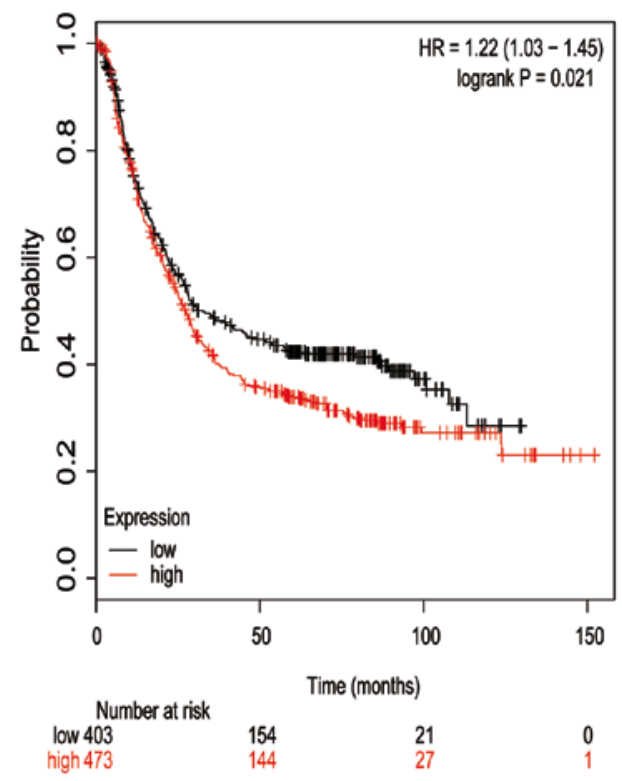

B

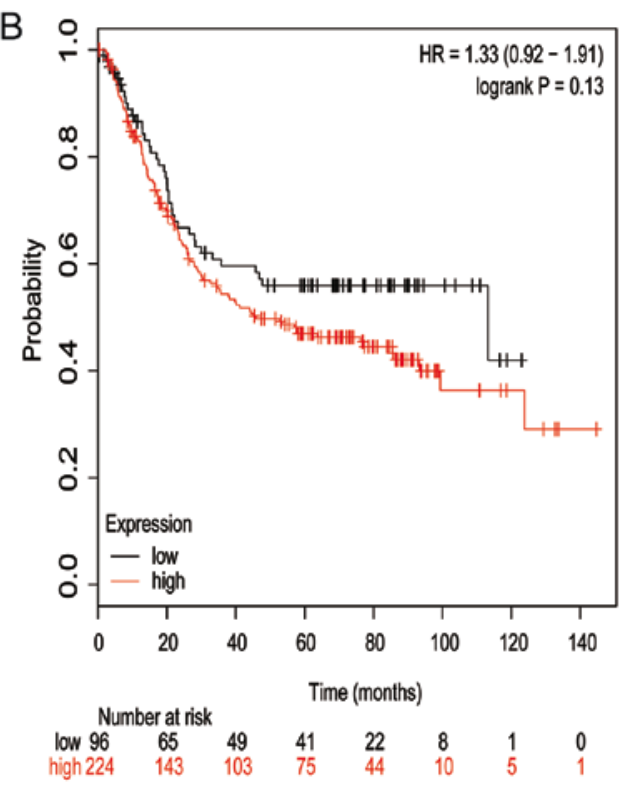

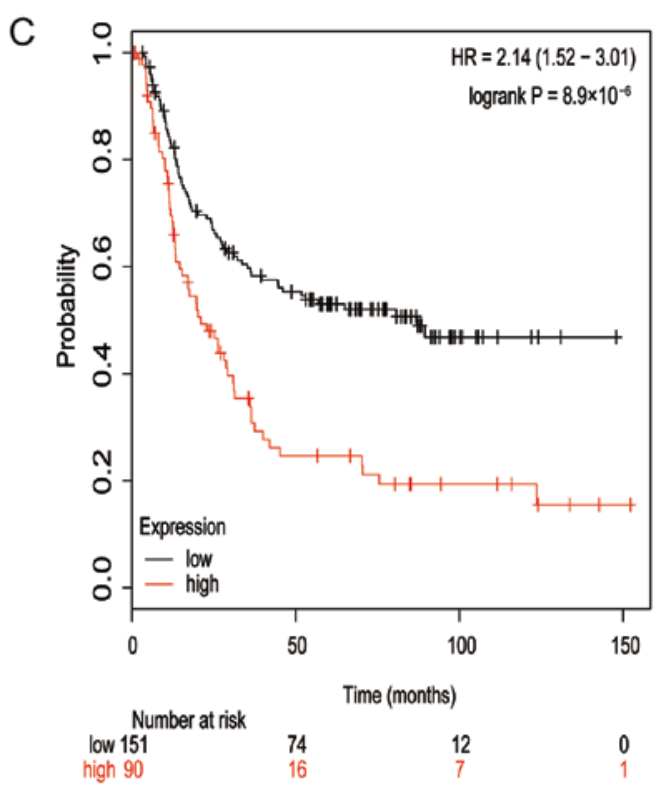

Figure 4. Determination of the prognostic value of TGF $\beta$ R1 mRNA expression using the K-M plotter online tool. The desired Affymetrix IDs is valid: 204731_at (TGFßR3). Survival curves representing overall survival time for (A) total patients with GC $(\mathrm{n}=876)$, (B) patients with intestinal type GC $(\mathrm{n}=320)$ and (C) patients with diffuse type $\mathrm{GC}(\mathrm{n}=241)$. Patients were divided according to low- and high-TGF $\beta 1 \mathrm{mRNA}$ expression prior to survival curves being plotted. HR, hazard ratio; GC, gastric cancer; TGF $\beta$ R3, transforming growth factor receptor $\beta 3$.

1.48; 95\% CI, 1.16-1.88; P=0.0013; Table II) (HER2: HR,1.32; 95\% CI, 1.01-1.72; $\mathrm{P}=0.041$, Table II)] were associated with a better prognosis in both HER2 ${ }^{-}$and HER $2^{+}$patients with GC.

Low mRNA expression of TGF $\beta 1$ (HR, $0.60 ; 95 \% \mathrm{CI}$, 0.37-0.99; $\mathrm{P}=0.042$; Table III) and TGF $\beta$ R2 (HR, 0.57; 95\% CI, 0.37-0.89; $\mathrm{P}=0.012$; Table III) was associated with higher OS time in grade I patients with GC. Additionally, TGF $\beta R 1$ low mRNA expression was associated with higher OS time in grade II patients with GC (HR, 2.62; 95\% CI, 1.32-5.20; $\mathrm{P}=0.0041$; Table III). Low expression of TGF $\beta \mathrm{R} 3$ was associated with higher OS time in pathological grades II (HR, 0.29; 95\% CI, 0.08-1.03; P=0.043; Table III) and III (HR, 4.48; 95\% CI, 1.04-19.34; P=0.028; Table III) patients with GC.
Finally, as represented in Table IV, low mRNA expression of TGF $\beta 1$ was associated with higher OS times in patients with GC who had been treated with surgery alone (HR, 2.19; 95\% CI, 1.47-3.25; $\mathrm{P}<0.0001)$. Concurrently, low mRNA expression levels of TGF $\beta$ R 1 were associated with higher OS times in patients with GC with the same method of treatment (HR, 1.53; 95\% CI, 1.14-2.04; P=0.004; Table IV) and patients with GC who had fluorouracil (5-FU)-based adjuvant treatment (HR, 0.66; 95\% CI, 0.47-0.94; P=0.02; Table IV). Low mRNA expression of TGF $\beta$ R2 was associated with higher OS times in patients with GC who had received surgery alone (HR, 1.37; 95\% CI, 1.03-1.84; $\mathrm{P}=0.031$; Table IV) and patients with GC who had received 5-FU-based adjuvant treatment (HR, 0.42; 95\% CI, 0.29-0.61; P<0.0001; Table IV). Low mRNA 
Table I. Association between mRNA expression of TGF $\beta 1$ and its receptors and clinical stage in patients with gastric cancer.

\begin{tabular}{|c|c|c|c|c|c|}
\hline Gene & Clinical stages & Cases, $\mathrm{n}$ & HR & $95 \% \mathrm{CI}$ & P-value \\
\hline \multirow[t]{4}{*}{ TGF $\beta 1$} & 1 & 69 & 3.92 & $0.89-17.33$ & 0.052 \\
\hline & 2 & 145 & 2.61 & 1.16-5.86 & $0.016^{\mathrm{a}}$ \\
\hline & 3 & 319 & 0.77 & $0.58-1.03$ & 0.074 \\
\hline & 4 & 152 & 0.84 & $0.57-1.24$ & 0.380 \\
\hline \multirow[t]{4}{*}{ TGF $\beta R 1$} & 1 & 69 & 1.95 & $0.61-6.19$ & 0.250 \\
\hline & 2 & 145 & 3.39 & $1.86-6.61$ & $<0.001^{\mathrm{c}}$ \\
\hline & 3 & 319 & 1.90 & $1.42-2.55$ & $<0.001^{\mathrm{c}}$ \\
\hline & 4 & 152 & 1.39 & $0.94-2.07$ & 0.100 \\
\hline \multirow[t]{4}{*}{ TGF $\beta R 2$} & 1 & 69 & 9.10 & $1.19-69.51$ & $0.010^{\mathrm{a}}$ \\
\hline & 2 & 145 & 2.32 & $1.27-4.25$ & $0.005^{\mathrm{b}}$ \\
\hline & 3 & 319 & 1.28 & $0.96-1.71$ & 0.090 \\
\hline & 4 & 152 & 1.76 & $1.13-2.67$ & $0.012^{\mathrm{a}}$ \\
\hline \multirow[t]{4}{*}{ TGF $\beta$ R3 } & 1 & 69 & 1.63 & $0.60-4.41$ & 0.330 \\
\hline & 2 & 145 & 2.79 & $1.53-5.08$ & $<0.001^{\mathrm{c}}$ \\
\hline & 3 & 319 & 1.36 & $1.02-1.80$ & $0.035^{\mathrm{a}}$ \\
\hline & 4 & 152 & 2.00 & $1.33-3.00$ & $<0.001^{\mathrm{c}}$ \\
\hline
\end{tabular}

${ }^{\mathrm{a}} \mathrm{P}<0.05,{ }^{\mathrm{b}} \mathrm{P}<0.01,{ }^{\mathrm{c}} \mathrm{P}<0.001$. HR, hazard ratio; $\mathrm{CI}$, confidence interval; TGF, transforming growth factor; TGF $\beta \mathrm{R} 1$, transforming growth factor receptor $\beta 1$; TGF $\beta R 2$, transforming growth factor receptor $\beta 2$; TGF $\beta$ R3, transforming growth factor receptor $\beta 3$.

Table II. Association between mRNA expression of TGF $\beta 1$ and its receptors and HER 2 status of patients with gastric cancer.

\begin{tabular}{|c|c|c|c|c|c|}
\hline Gene & HER status & Cases, $\mathrm{n}$ & HR & $95 \%$ CI & P-value \\
\hline \multirow[t]{2}{*}{ TGF $\beta 1$} & - & 532 & 1.66 & $1.27-2.15$ & $<0.001^{\mathrm{c}}$ \\
\hline & + & 344 & 1.26 & $0.96-1.65$ & 0.090 \\
\hline \multirow[t]{2}{*}{ TGF $\beta R 1$} & - & 532 & 1.67 & $1.33-2.09$ & $<0.001^{\mathrm{c}}$ \\
\hline & + & 344 & 1.48 & $1.14-1.92$ & $0.003^{\mathrm{b}}$ \\
\hline \multirow[t]{2}{*}{ TGF $\beta$ R2 } & - & 532 & 1.33 & $1.05-1.67$ & $0.016^{\mathrm{a}}$ \\
\hline & + & 344 & 0.76 & $0.57-1.03$ & 0.072 \\
\hline \multirow[t]{2}{*}{ TGF $\beta R 3$} & - & 532 & 1.48 & $1.16-1.88$ & 0.001 \\
\hline & + & 344 & 1.32 & $1.01-1.72$ & $0.041^{\mathrm{a}}$ \\
\hline
\end{tabular}

${ }^{\mathrm{a}} \mathrm{P}<0.05,{ }^{\mathrm{b}} \mathrm{P}<0.01,{ }^{\mathrm{c}} \mathrm{P}<0.001$. HR, hazard ratio; $\mathrm{CI}$, confidence interval; TGF, transforming growth factor; TGF $\beta \mathrm{R} 1$, transforming growth factor receptor $\beta 1$; TGF $\beta$ R2, transforming growth factor receptor $\beta 2$; TGF $\beta$ R3, transforming growth factor receptor $\beta 3$.

expression of TGF $\beta$ R 3 was associated with higher OS times in patients with GC who were surgically treated (HR, 1.52; 95\% CI, 1.12-2.07; P=0.0075; Table IV) and patients with GC who were treated with a 5-FU-based adjuvant (HR, 0.60; 95\% CI 0.40-0.89; $\mathrm{P}=0.01$; Table IV). The low expression levels of TGF $\beta 1$ (HR, 2.72; 95\% CI, 1.12-6.58; $\mathrm{P}=0.021)$ and TGF $\beta$ R3 (HR, 3.27; 95\% CI, 1.26-8.52; P=0.01) (Table IV) were associated with higher OS times in patients receiving other adjuvant treatments.

Knockdown of TGF $\beta 1$ and its receptors inhibits the proliferation of human $G C$ cells. Since a high mRNA expression level of TGF $\beta 1$ and its receptors is predicative of a poor prognosis in patients with $\mathrm{GC}$, their direct effects on $\mathrm{GC}$ cells were subsequently investigated. In order to evaluate the role of
TGF $\beta 1$ and its receptors in AGS and MKN45 cells, specific siRNAs were transfected into cells and expression was quantified by RT-qPCR and western blotting. As presented in Fig. 5, the expression of TGF $\beta 1$ and its receptors was significantly suppressed in transfected GC cells. The proliferation of AGS and MKN45 cells was then determined using a CCK8 assay. Based on these results, it was determined that the knockdown of TGF $\beta 1$ and its receptors (with the exception of TGF $\beta R 3$ ) inhibited the proliferation of GC cells (Fig. 6A and B).

Knockdown of TGF $\beta 1$ and its receptors inhibits the migration and invasion of human GC cells. Next, transwell assays were performed to explore the effects of TGF $\beta 1$ and its receptors on the migration and invasion of $\mathrm{GC}$ cells (Fig. 6C). With the exception of TGF $\beta$ R3, TGF $\beta 1$ and 
Table III. Association between mRNA expression of TGF $\beta 1$ and its receptors and pathological grades of patients with gastric cancer.

\begin{tabular}{|c|c|c|c|c|c|}
\hline Gene & Pathological grades & Cases, $\mathrm{n}$ & HR & $95 \% \mathrm{CI}$ & P-value \\
\hline \multirow[t]{3}{*}{ TGF $\beta 1$} & I & 166 & 0.60 & $0.37-0.99$ & $0.042^{\mathrm{a}}$ \\
\hline & II & 67 & 0.57 & $0.30-1.09$ & 0.087 \\
\hline & III & 32 & 0.74 & $0.30-1.78$ & 0.500 \\
\hline \multirow[t]{3}{*}{ TGF $\beta R 1$} & I & 166 & 1.52 & $0.93-2.50$ & 0.094 \\
\hline & II & 67 & 2.62 & $1.32-5.20$ & $0.004^{\mathrm{b}}$ \\
\hline & III & 32 & 2.23 & $0.68-7.90$ & 0.170 \\
\hline \multirow[t]{3}{*}{ TGF $\beta R 2$} & I & 166 & 0.57 & $0.37-0.89$ & $0.012^{\mathrm{a}}$ \\
\hline & II & 67 & 2.16 & $0.90-5.19$ & 0.078 \\
\hline & III & 32 & 0.67 & $0.27-1.63$ & 0.370 \\
\hline \multirow[t]{3}{*}{ TGF $\beta R 3$} & I & 166 & 1.20 & $0.79-1.83$ & 0.390 \\
\hline & II & 67 & 0.29 & $0.08-1.03$ & $0.043^{\mathrm{a}}$ \\
\hline & III & 32 & 4.48 & $1.04-19.34$ & $0.028^{\mathrm{a}}$ \\
\hline
\end{tabular}

${ }^{\mathrm{a}} \mathrm{P}<0.05,{ }^{\mathrm{b}} \mathrm{P}<0.01,{ }^{\mathrm{C}} \mathrm{P}<0.001$. HR, hazard ratio; $\mathrm{CI}$, confidence interval; TGF, transforming growth factor; TGF $\beta \mathrm{R} 1$, transforming growth factor receptor $\beta 1$;GF $\beta$ R2, transforming growth factor receptor $\beta 2$; TGF $\beta$ R3, transforming growth factor receptor $\beta 3$.

Table IV. Association between mRNA expression of TGF $\beta 1$ and its receptors and different treatment methods of patients with gastric cancer.

\begin{tabular}{|c|c|c|c|c|c|}
\hline Gene & Treatment: & Cases, $\mathrm{n}$ & HR & $95 \% \mathrm{CI}$ & P-value \\
\hline \multirow[t]{3}{*}{ TGF $\beta 1$} & Surgery only & 393 & 2.19 & $1.47-3.25$ & $<0.001^{\mathrm{c}}$ \\
\hline & $5 \mathrm{FU}$ based adjuvant & 158 & 0.84 & $0.58-1.22$ & $<0.001^{\mathrm{c}}$ \\
\hline & Other adjuvant & 80 & 2.72 & $1.12-6.58$ & $0.021^{\mathrm{a}}$ \\
\hline \multirow[t]{3}{*}{ TGF $\beta R 1$} & Surgery only & 393 & 1.53 & $1.14-2.04$ & $0.004^{\mathrm{b}}$ \\
\hline & 5 FU based adjuvant & 158 & 0.66 & $0.47-0.94$ & $0.020^{\mathrm{a}}$ \\
\hline & Other adjuvant & 80 & 1.69 & $0.70-4.09$ & 0.240 \\
\hline \multirow[t]{3}{*}{ TGF $\beta R 2$} & Surgery only & 393 & 1.37 & $1.03-1.84$ & $0.031^{\mathrm{a}}$ \\
\hline & 5 FU based adjuvant & 158 & 0.42 & $0.29-0.61$ & $<0.001^{\mathrm{c}}$ \\
\hline & Other adjuvant & 80 & 1.66 & $0.69-4.00$ & 0.260 \\
\hline \multirow[t]{3}{*}{ TGF $\beta$ R3 } & Surgery only & 393 & 1.52 & $1.12-2.07$ & $0.008^{\mathrm{b}}$ \\
\hline & 5 FU based adjuvant & 158 & 0.60 & $0.40-0.89$ & $0.010^{\mathrm{a}}$ \\
\hline & Other adjuvant & 80 & 3.27 & $1.26-8.52$ & $0.010^{\mathrm{a}}$ \\
\hline
\end{tabular}

${ }^{\mathrm{a}} \mathrm{P}<0.05$, ${ }^{\mathrm{b}} \mathrm{P}<0.01,{ }^{\mathrm{c}} \mathrm{P}<0.001$. HR, hazard ratio; $\mathrm{CI}$, confidence interval; TGF $\beta \mathrm{R} 1$, transforming growth factor receptor $\beta 1$; TGF $\beta R 2$, transforming growth factor receptor $\beta 2$; TGF $\beta$ R , transforming growth factor receptor $\beta 3$.

its receptors significantly inhibited the migration of AGS and MKN45 cells (Fig. 6C-E). Moreover, the results of the transwell assay for cell invasion demonstrated that except for TGF $\beta 1$, knockdown of TGF $\beta 1$ and its receptors suppressed cell invasiveness (Fig. 6C-E). Cumulatively, the data confirm that knockdown of TGF $\beta 1$, TG $\beta \beta R 1$ and TGF $\beta R 2$ inhibit the progression of human GC.

\section{Discussion}

The TGF $\beta$ superfamily is a large class of cytokines that perform various biological activities. This superfamily is mainly comprised of TGF $\beta$, activin and bone morphogenetic protein. These molecules are important in the regulation of cell growth, adhesion, migration, differentiation and apoptosis. In mammals, three subtypes of TGF $\beta$ have been discovered: TGF $\beta 1$; TGF $\beta 2$; and TGF $\beta 3$ (31). TGF $\beta 1$ is the most commonly expressed form of TGF $\beta$ in human tissues, and plays an important role in the regulation of cell growth, apoptosis, differentiation and the maintenance of normal immune homeostasis (32-34). TGF $\beta$ signaling is a double-edged sword in the process of tumor formation and development (35). In tumor formation, the TGF $\beta$ signaling pathway regulates downstream target genes, such as $\mathrm{p} 21$ cyclin dependent kinase (CDKN)1A and p15CDKN2B, to arrest cells in the $\mathrm{G}_{1}$ phase of the cell cycle, and inhibit the proliferation of tumor cells (35). In 
A

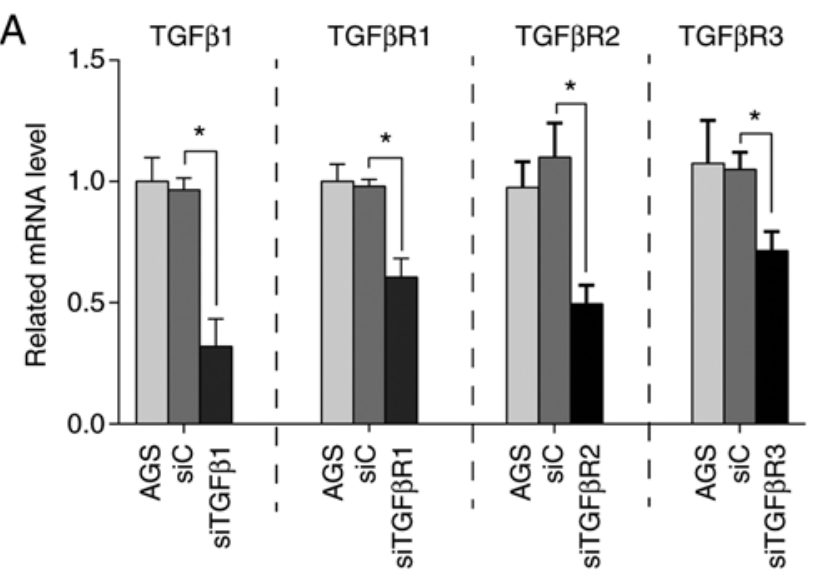

C
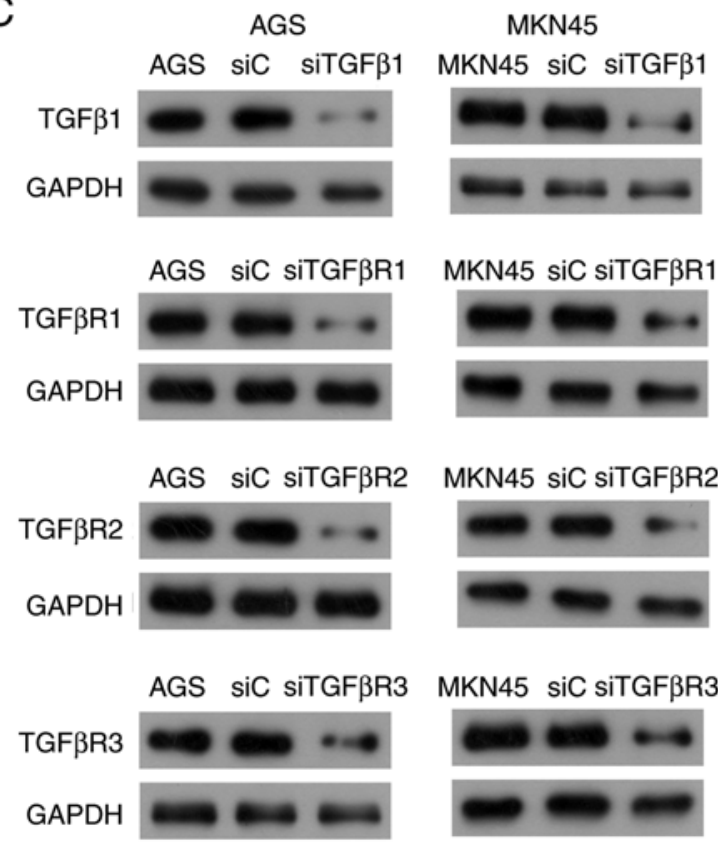

B

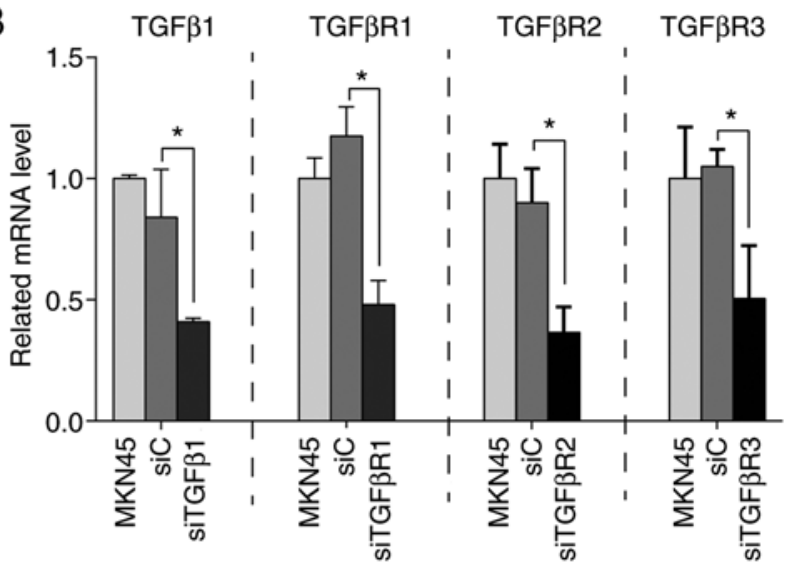

D
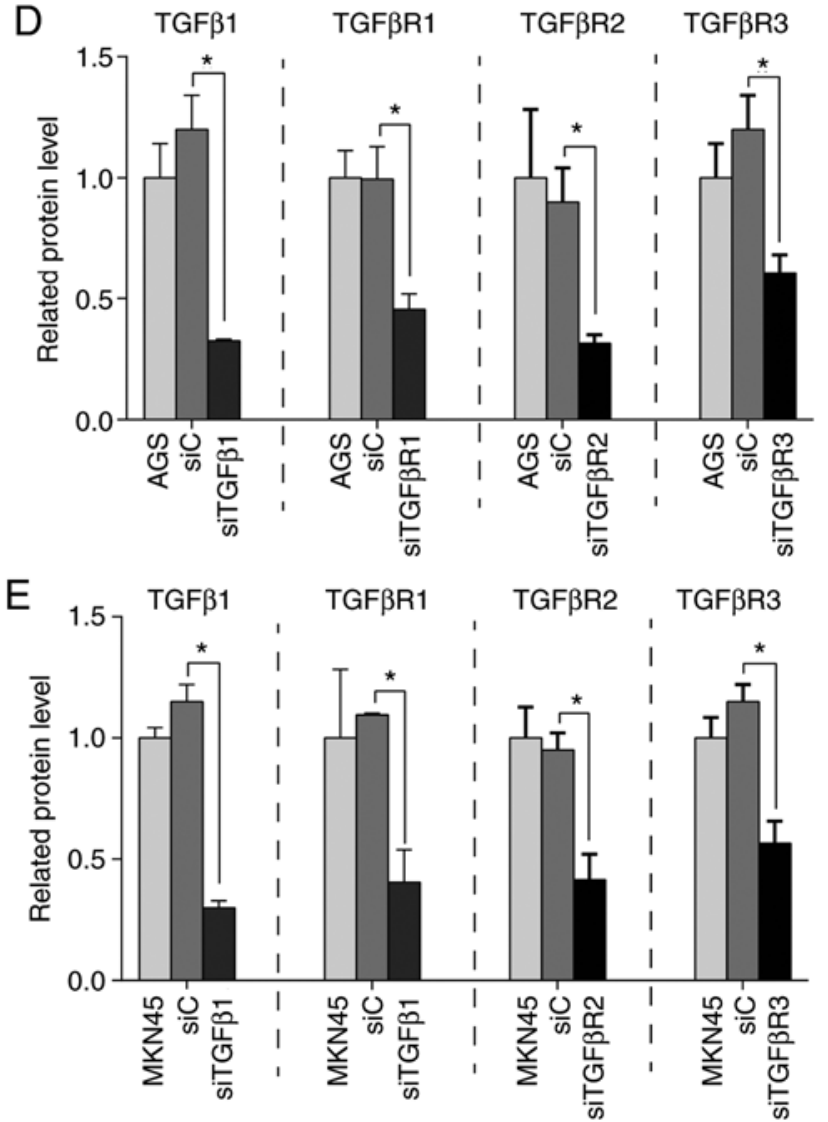

Figure 5. Inhibition of the expression of TGF $\beta 1$ and its receptors by specific siRNAs. mRNA levels of TGF $\beta 1$ and its receptors were detected using reverse transcription-quantitative PCR in (A) AGS and (B) MKN45 cells. (C) Protein expression level of TGF $\beta 1$ and its receptors was detected by western blot. Protein levels of TGF $\beta 1$ and its receptors in (D) AGS and (E) MKN45 cells as analyzed by ImageJ software. ${ }^{*} \mathrm{P}<0.05$. TGF $\beta 1$, transforming growth factor $\beta 1$; TGF $\beta R 1$, transforming growth factor receptor $\beta 1$; TGF $\beta R 2$, transforming growth factor receptor $\beta 2$; TGF $\beta$ R3, transforming growth factor receptor $\beta 3$.

tumor progression, TGF $\beta$ can promote invasion and metastasis through a variety of mechanisms, including immune suppression or escape, angiogenesis and by increasing the interaction between tumor cells and the extracellular matrix (35).

In previous years, numerous studies have demonstrated that TGF $\beta 1$ is associated with tumor occurrence and development, and is highly expressed in a variety of malignant tumor types, including prostate, breast gastric and colorectal cancer $(36,37)$. Docea et al (38) noticed that the highest level of TGF $\beta$ was exhibited in GC compared with normal tissue and the expression of TGF $\beta$ progressively increased in the epithelium-intestinal metaplasia-dysplasia-carcinoma sequence. In intestinal variants, TGF $\beta$ immunoreactivity was significantly associated with the degree of tumor differentiation and proliferative activity (38). According to another report, TGF $\beta 1$ mRNA levels were higher in tumor cells and were positively associated with Smad 2 and Smad7 mRNA levels (39). Serum TGF 31 levels have been demonstrated to be significantly higher in patients at both early and advanced cancer stages, compared with controls (39). TGF $\beta 1$ is closely linked to the initiation of the epithelial-mesenchymal transition (EMT) in the development and progression of carcinomas $(40,41)$. In GC cells, TGF $\beta 1$ can induce the mRNA and protein expression of Krüppel-like factor 8 expression (42). It can also contribute to EMT via the downregulation of E-cadherin, and the upregulation of vimentin expression (43-45). TGF $\beta 1$ can interact with a variety 


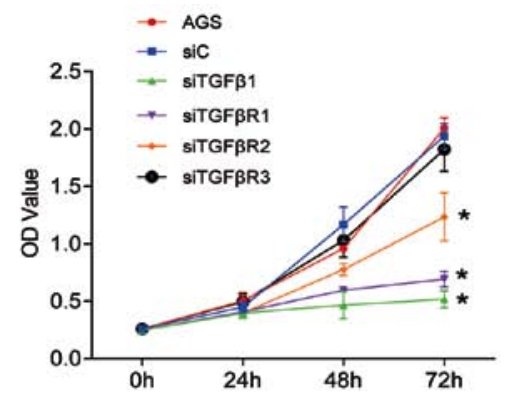

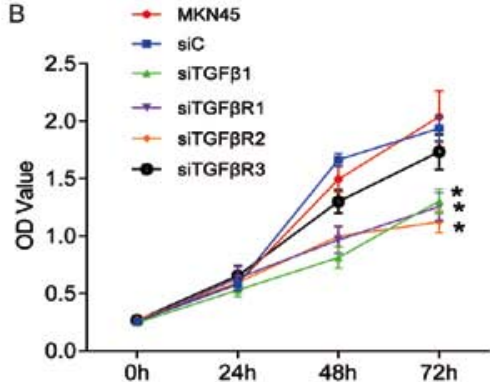

C
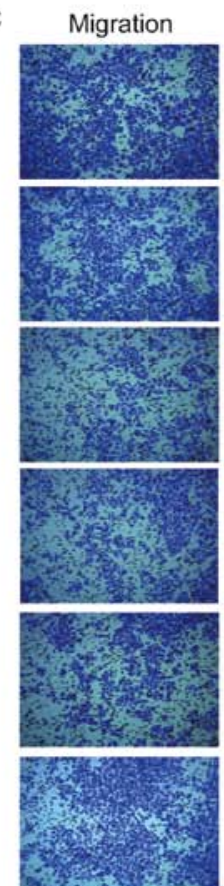

Invasion
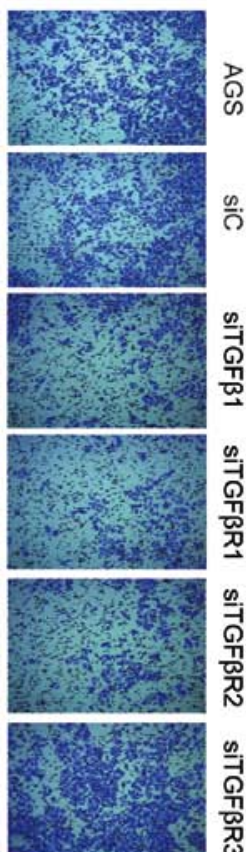

Migration
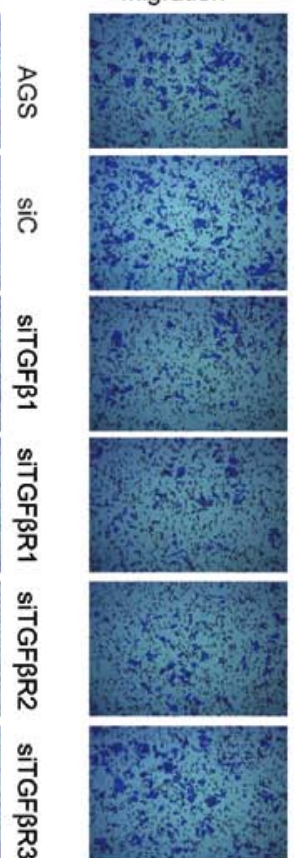

Invasion
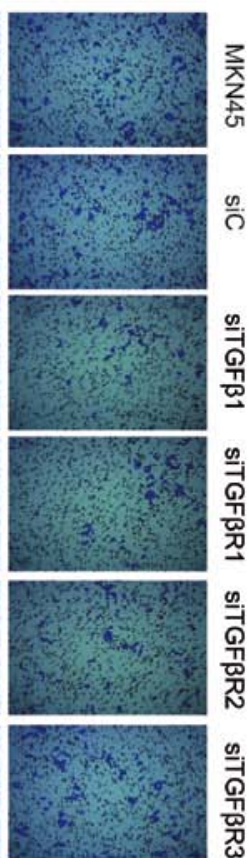

D
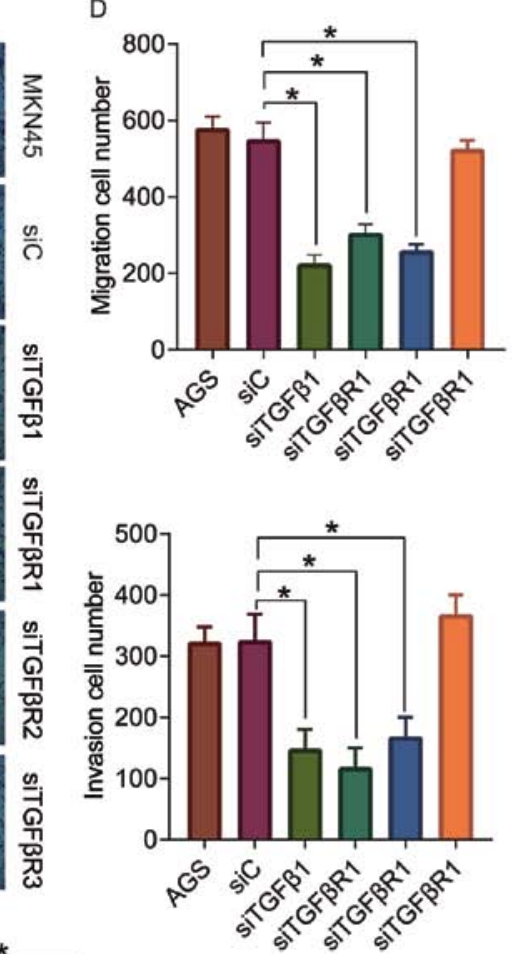

E
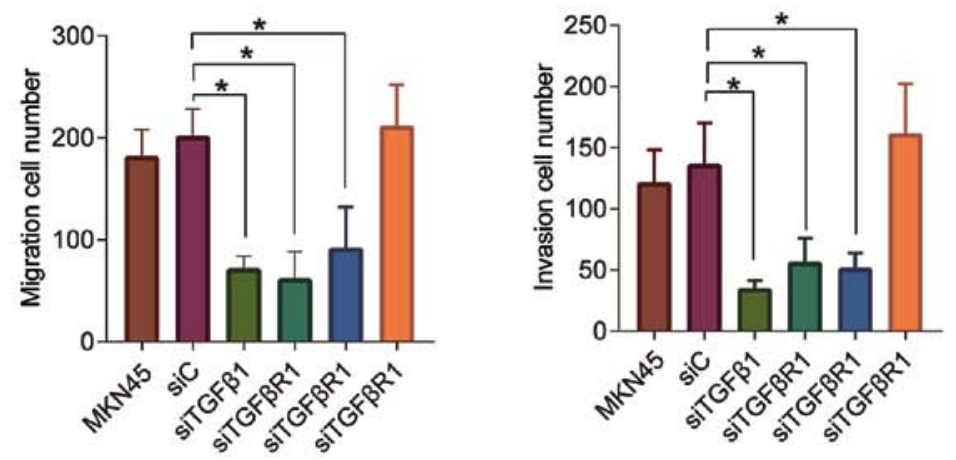

Figure 6. Inhibition of proliferation and induction of apoptosis by TGF $\beta 1$ and its receptors in human gastric cancer cell lines. The Cell Counting Kit-8 assay was performed to detect the proliferation of (A) AGS and (B) MKN45 cells. (C) Transwell assays were performed to analyze the migration and invasion of AGS and MKN45 cells. Column diagram showed the statistical analysis of migration and invasion cell number of (D) AGS and (E) MKN45 cells. "P<0.05. $\mathrm{siC}$, small interfering control; si, small interfering RNA; TGF $\beta$ R1, transforming growth factor receptor $\beta 1$; TGF $\beta$ R2, transforming growth factor receptor $\beta 2$; TGF $\beta R 3$, transforming growth factor receptor $\beta 3$.

of tumor-related genes and proteins in TGF $\beta$-induced EMT in GC, such as SAM-domain and SH3-domain containing 1, microRNA-21 and Grainy head like 2 (43-45). In the present study, low mRNA expression of TGF $\beta 1$ was associated with an improved prognosis in patients with GC, including the intestinal and diffuse subtypes of GC. In addition, TGF $\beta 1$ can be associated with patient prognosis in GC, based on certain clinical features, including HER2 status, pathological grade I and different treatment methods. These results suggest that
TGF $\beta 1$ has potential as a new prognostic indicator of GC, including the intestinal and diffuse types.

The TGF $\beta R$ includes three subtypes: TGF $\beta R 1$, TGF $\beta R 2$ and TGF $\beta$ R3. TGF $\beta$ R1 and 2 are categorized as type I transmembrane glycoproteins with serine/threonine kinase activity and collectively participate in the TGF $\beta / \mathrm{Smad}$ signaling pathway. Initially, TGF $\beta$ binds to TGF $\beta$ R2, and then activates TGF $\beta$ R3 through phosphorylation. Together they form the TGF $\beta$ R 1-TGF $\beta 1$-TGF $\beta$ R2 heterotetramer for transduction of 
cell signaling. TGF $\beta$ R 3 can enhance the binding of ligand to TGF $\beta R 1$ and 2, functioning as an accessory receptor (14). Wild-type TGF $\beta R 2$ expression in GC cell lines can result in reduced proliferation compared with control cells (46). A case-control study was performed to evaluate the possible association of polymorphisms in TGF- $\beta$ receptors with susceptibility to developing GC (47).

Polymorphisms of TGF $\beta R 1$ and 2 may be associated with the risk of GC in the population of North China $(48,49)$. However, TGF $\beta$ R3 has not yet been studied in the context of GC. In the present study, it was revealed that low mRNA expression of TGF $\beta R 1$, TGF $\beta$ R2 and TGF $\beta$ R 3 was associated with a more favorable prognosis in patients with GC. While TGF $\beta$ R2 was associated with OS time in patients with intestinal type GC, this was not observed for patients with diffuse type GC. Pak et al (50) determined that the expression of T $\beta R 2$ was higher in patients with intestinal type GC compared with those with diffuse type GC. In addition, TGF $\beta$ R was also associated with prognosis based on different clinical features in the aforementioned study (50). While TGF $\beta 1$ blockade has been proposed as an anti-cancer therapy, it is imperative to understand the best method of administration, and which specific pathological features will be most improved by this therapy (51).

Finally, the present study investigated the specific roles of TGF $\beta 1$ and its receptors on GC cells. The results of the present study demonstrated that knockdown of TGF $\beta 1$, TGF $\beta$ R 1 and TGF $\beta$ R 2 could significantly suppress the proliferation, migration and invasion of human GC cells. These results are consistent with previous studies $(48,52-54)$. While TGF $\beta$ R2 has been widely studied in different types of cancer $(54,55)$, studies investigating TGF $\beta R 1$ and TGF $\beta$ R3 are limited. The current study confirms the inhibitory effect of TGF $\beta R 1$ on the proliferation of GC cells, suggesting the involvement of TGF $\beta 1$ and TGF $\beta R 2$, but also TGF $\beta$ R1 in the progression of GC. However, the downstream targets and regulatory mechanism of TGF $\beta R 1$ remain unclear, and cells cultured in vitro cannot precisely simulate the tumor microenvironment. The results of the present study need to be verified by further in vivo experiments.

In conclusion, the present study showed that TGF $\beta 1$ and its receptors were all associated with the prognosis of patients with GC. Consistently, low mRNA expression levels of TGF $\beta 1$ and TGF $\beta R$ indicated a better OS time. Furthermore, knockdown of TGF $\beta 1$, TGF $\beta$ R 1 and TGF $\beta R 2$ inhibited cell proliferation in GC. This suggests that TGF $\beta 1$ and TGF $\beta R$ play important roles in the development of GC and may be investigated as therapeutic targets. These findings provide novel insights and approaches for the treatment of GC.

\section{Acknowledgements}

Not applicable.

\section{Funding}

No funding was received.

\section{Availability of data and materials}

The datasets used and/or analyzed during the current study are available from the corresponding author on reasonable request.

\section{Authors' contributions}

FL and HW mainly performed the experiments and analyzed the data. FL performed the online analysis and wrote the paper. MZ carried out the experiment design and manuscript drafting. All authors have read and approved the manuscript.

\section{Ethics approval and consent to participate}

Not applicable.

\section{Patient consent for publication}

Not applicable.

\section{Competing interests}

The authors declare that they have no competing interests.

\section{References}

1. Kamangar F, Dores GM and Anderson WF: Patterns of cancer incidence, mortality, and prevalence across five continents: Defining priorities to reduce cancer disparities in different geographic regions of the world. J Clin Oncol 24: 2137-2150, 2006.

2. Jemal A, Bray F, Center MM, Ferlay J, Ward E and Forman D: Global cancer statistics. CA Cancer J Clin 61: 69-90, 2011.

3. Alberts SR, Cervantes A and van de Velde CJ: Gastric cancer: Epidemiology, pathology and treatment. Ann Oncol 14 (Suppl 2): ii31-ii36, 2003.

4. Choi YY, Noh SH and Cheong JH: Evolution of gastric cancer treatment: From the golden age of surgery to an era of precision medicine. Yonsei Med J 56: 1177-1185, 2015.

5. Chang HM, Lee SW, Nomura E and Tanigawa N: Laparoscopic versus open gastrectomy for gastric cancer patients with COPD. J Surg Oncol 100: 456-458, 2009.

6. Foidart JM and Muschel RJ (eds): Proteases and Their Inhibitors in Cancer Metastasis. Kluwer Academic Publicers, The Netherlands, pp225-252, 2002.

7. Mesri M, Wall NR, Li J, Kim RW and Altieri DC: Cancer gene therapy using survivin mutant adenovirus. J Clin Invest 108: 981-990, 2001 .

8. Liang L, Fang JY and Xu J: Gastric cancer and gene copy number variation: Emerging cancer drivers for targeted therapy. Oncogene 35: 1475-1482, 2016.

9. Lin Y, Wu Z, Guo W and Li J: Gene mutations in gastric cancer: A review of recent next-generation sequencing studies. Tumour Biol 36: 7385-7394, 2015.

10. Kajdaniuk D, Marek B, Borgielmarek H and Koskudła B: Transforming growth factor $\beta 1$ (TGF $\beta 1$ ) in physiology and pathology. Endokrynol Pol 64: 384-396, 2013.

11. Massagué J: TGF-beta signal transduction. Annu Rev Biochem 67: 753-791, 1998.

12. Assoian RK, Komoriya A, Meyers CA, Miller DM and Sporn MB: Transforming growth factor-beta in human platelets. Identification of a major storage site, purification, and characterization. J Biol Chem 258: 7155-7160, 1983.

13. Sam R, Wanna L, Gudehithlu KP, Garber SL, Dunea G, Arruda JA and Singh AK: Glomerular epithelial cells transform to myofibroblasts: Early but not late removal of TGF-beta1 reverses transformation. Transl Res 148: 142-148, 2006

14. Ikushima $\mathrm{H}$ and Miyazono K: TGFbeta signalling: A complex web in cancer progression. Nat Rev Cancer 10: 415-424, 2010.

15. Massagué J: TGFbeta in cancer. Cell 134: 215-230, 2008.

16. Zhuang J, Lu Q, Shen B, Huang X, Shen L, Zheng X, Huang R, Yan J and Guo H: TGF $\beta 1$ secreted by cancer-associated fibroblasts induces epithelial-mesenchymal transition of bladder cancer cells through lncRNA-ZEB2NAT. Sci Rep 5: 11924, 2015.

17. Neuzillet C, Tijeras-Raballand A, Cohen R, Cros J, Faivre S, Raymond E and de Gramont A: Targeting the TGF $\beta$ pathway for cancer therapy. Pharmacol Ther 147: 22-31, 2015. 
18. Busch S, Acar A, Magnusson Y, Gregersson P, Rydén L and Landberg G: TGF-beta receptor type-2 expression in cancer-associated fibroblasts regulates breast cancer cell growth and survival and is a prognostic marker in pre-menopausal breast cancer. Oncogene 34: 27-38, 2015.

19. Ji Q, Liu X, Han Z, Zhou L, Sui H, Yan L, Jiang H, Ren J, Cai J and Li Q: Resveratrol suppresses epithelial-to-mesenchymal transition in colorectal cancer through TGF- $\beta 1 /$ Smads signaling pathway mediated Snail/E-cadherin expression. BMC Cancer 15: 97, 2015.

20. Ma ZL, Hou PP, Li YL, Wang DT, Yuan TW, Wei JL, Zhao BT, Lou JT, Zhao XT, Jin Y and Jin YX: MicroRNA-34a inhibits the proliferation and promotes the apoptosis of non-small cell lung cancer H1299 cell line by targeting TGF $\beta$ R2. Tumour Biol 36 : 2481-2490, 2015

21. Szász AM, Lánczky A, Nagy Á, Förster S, Hark K, Green JE, Boussioutas A, Busuttil R, Szabó A and Győrffy B: Cross-validation of survival associated biomarkers in gastric cancer using transcriptomic data of 1,065 patients. Oncotarget 7 : 49322-49333, 2016.

22. Wu X, Liu W, Tang D, Xiao H, Wu Z, Chen C, Yao X, Liu F and $\mathrm{Li} \mathrm{G}$ : Prognostic values of four Notch receptor mRNA expression in gastric cancer. Sci Rep 6: 28044, 2016.

23. Zhang S, Zhen W, Liu W, Lei R, Shan J, Li L and Wang X: Distinct prognostic values of S100 mRNA expression in breast cancer. Sci Rep 7: 39786, 2017.

24. Wu S, Xue W, Huang X, Yu X, Luo M, Huang Y, Liu Y, Bi Z, Qiu X and Bai S: Distinct prognostic values of ALDH1 isoenzymes in breast cancer. Tumor Biol 36: 2421-2426, 2015.

25. Zhou X, Teng L and Wang M: Distinct prognostic values of four-Notch-receptor mRNA expression in ovarian cancer. Tumor Biol 37: 6979-6985, 2016

26. Ivanova L, Zandberga E, Silina K, Kalnina Z, Ābols A, Endzeliņ̌s E, Vendina I, Romanchikova N', Hegmane A, Trapencieris $\mathrm{P}$, et al: Prognostic relevance of carbonic anhydrase IX expression is distinct in various subtypes of breast cancer and its silencing suppresses self-renewal capacity of breast cancer cells. Cancer Chemother Pharmacol 75: 235-246, 2015.

27. Győrffy B, Surowiak P, Budczies J and Lánczky A: Online survival analysis software to assess the prognostic value of biomarkers using transcriptomic data in non-small-cell lung cancer. PLoS One 8: e82241, 2013.

28. Sun Z, Wang ZN, Zhu Z, Xu YY, Xu Y, Huang BJ, Zhu GL and $\mathrm{Xu}$ HM: Evaluation of the seventh edition of American Joint Committee on Cancer TNM staging system for gastric cancer: Results from a Chinese monoinstitutional study. Ann Surg Oncol 19: 1918-1927, 2012.

29. Ma J, Shen H, Kapesa L and Zeng S: Lauren classification and individualized chemotherapy in gastric cancer. Oncol Lett 11: 2959-2964, 2016.

30. Livak KJ and Schmittgen TD: Analysis of relative gene expression data using real-time quantitative PCR and the 2(-Delta Delta C(T)) method. Methods 25: 402-408, 2001

31. Memon MA, Anway MD, Covert TR, Uzumcu M and Skinner MK: Transforming growth factor beta (TGFbeta1, TGFbeta2 and TGFbeta3) null-mutant phenotypes in embryonic gonadal development. Mol Cell Endocrinol 294: 70-80, 2008.

32. Meng XM, Tang PM, Li J and Lan HY: TGF- $\beta /$ Smad signaling in renal fibrosis. Front Physiol 6: 82, 2015.

33. Okamura T, Morita K, Iwasaki Y, Inoue M, Komai T, Fujio K and Yamamoto K: Role of TGF- $\beta 3$ in the regulation of immune responses. Clin Exp Rheumatol 33 (Suppl 92): S63-S69, 2015.

34. Potter RM, Huynh RT, Volper BD, Arthur KA, D'Lugos AC Sørensen MA, Magnusson SP, Dickinson JM, Hale TM and Carroll CC: Impact of TGF- $\beta$ inhibition during acute exercise on Achilles tendon extracellular matrix. Am J Physiol Regul Integr Comp Physiol 312: R157-R164, 2017.

35. Akhurst RJ and Derynck R: TGF-beta signaling in cancer-a double-edged sword. Trends in Cell Biol 11: S44-S51, 2001

36. Costanza B, Umelo IA, Bellier J, Castronovo V and Turtoi A: Stromal modulators of TGF- $\beta$ in cancer. J Clin Med 6: pii: E7, 2017.

37. Pang MF, Georgoudaki AM, Lambut L, Johansson J, Tabor V, Hagikura K, Jin Y, Jansson M, Alexander JS, Nelson CM, et al: TGF- $\beta 1$-induced EMT promotes targeted migration of breast cancer cells through the lymphatic system by the activation of CCR7/CCL21-mediated chemotaxis. Oncogene 35: 748-760, 2016.
38. Docea AO, Mitrut P, Grigore D, Pirici D, Călina DC and Gofită E Immunohistochemical expression of TGF beta (TGF- $\beta$ ), TGF beta receptor 1 (TGFBR1), and Ki67 in intestinal variant of gastric adenocarcinomas. Rom J Morphol Embryol 53 (Suppl 3): 683-692, 2012.

39. Ma GF, Miao Q, Zeng XQ, Luo TC, Ma LL, Liu YM, Lian JJ, Gao H and Chen SY: Transforming growth factor- $\beta 1$ and $-\beta 2$ in gastric precancer and cancer and roles in tumor-cell interactions with peripheral blood mononuclear cells in vitro. PLoS One 8: e54249, 2013

40. David CJ, Huang YH, Chen M, Su J, Zou Y, Bardeesy N, Iacobuzio-Donahue CA and Massagué J: TGF- $\beta$ tumor suppression through a lethal EMT. Cell 164: 1015-1030, 2016.

41. Lamouille S, Xu J and Derynck R: Molecular mechanisms of epithelial-mesenchymal transition. Nat Rev Mol Cell Biol 15: 178-196, 2014.

42. Zhang H, Liu L, Wang Y, Zhao G, Xie R, Liu C, Xiao X, Wu K, Nie Y, Zhang H and Fan D: KLF8 involves in TGF-beta-induced EMT and promotes invasion and migration in gastric cancer cells. J Cancer Res Clin Oncol 139: 1033-1042, 2013.

43. Xiang J, Fu X, Ran W and Wang Z: Grhl2 reduces invasion and migration through inhibition of TGF $\beta$-induced EMT in gastric cancer. Oncogenesis 6: e284, 2017.

44. Li C, Song L, Zhang Z, Bai XX, Cui MF and Ma LJ: MicroRNA-21 promotes TGF- $\beta 1$-induced epithelial-mesenchymal transition in gastric cancer through up-regulating PTEN expression. Oncotarget 7: 66989-67003, 2016.

45. Zong W, Yu C, Wang P and Dong L: Overexpression of SASH inhibits TGF- $\beta 1$-induced EMT in gastric cancer cells. Oncol Res 24: 17-23, 2016.

46. Chang J, Park K, Bang YJ, Kim WS, Kim D and Kim SJ: Expression of transforming growth factor beta type II receptor reduces tumorigenicity in human gastric cancer cells. Cancer Res 57: 2856-2859, 1997.

47. Guo W, Dong Z, Guo Y, Chen Z, Yang Z and Kuang G: Association of polymorphisms in transforming growth factor- $\beta$ receptors with susceptibility to gastric cardia adenocarcinoma. Mol Biol Rep 39: 4301-4309, 2012.

48. Chen J, Miao L, Jin G, Ren C, Ke Q, Qian Y, Dong M, Li H, Zhang Q, Ding Y, et al: TGFBR1 tagging SNPs and gastric cancer susceptibility: A two-stage case-control study in Chinese population. Mol Carcinog 53: 109-116, 2014.

49. Xu L, Zeng Z, Chen B, Wu X, Yu J, Xue L, Tian L, Wang Y, Chen M, Sung JJ and Hu P: Association between the TGFB1 $-509 \mathrm{C} / \mathrm{T}$ and TGFBR $2-875 \mathrm{~A} / \mathrm{G}$ polymorphisms and gastric cancer: A case-control study. Oncol Lett 2: 371-377, 2011.

50. Pak KH, Dong HK, Kim H, Lee DH and Cheong JH: Differences in TGF- $\beta 1$ signaling and clinicopathologic characteristics of histologic subtypes of gastric cancer. BMC Cancer 16: 60, 2016.

51. Suzuki E, Kapoor V, Kaiser LR and Albelda SM: Soluble type II TGF- $\beta$ receptor augments or inhibits murine malignant mesothelioma tumor growth depending on when it is administered. Cancer Res 64: 5336, 2004.

52. Chen ZL, Qin L, Peng XB, Hu Y and Liu B: INHBA gene silencing inhibits gastric cancer cell migration and invasion by impeding activation of the TGF- $\beta$ signaling pathway. J Cell Physiol 234: 18065-18074, 2019.

53. Zhou $\mathrm{H}$, Wang $\mathrm{K}, \mathrm{Hu} \mathrm{Z}$ and Wen J: TGF- $\beta 1$ alters microRNA profile in human gastric cancer cells. Chin J Cancer Res 25: 102-111, 2013.

54. Duan J, Zhang H, Qu Y, Deng T, Huang D, Liu R, Zhang L, Bai M, Zhou L, Ying G and Ba Y: Onco-miR-130 promotes cell proliferation and migration by targeting TGF $3 \mathrm{R} 2$ in gastric cancer. Oncotarget 7: 44522-44533, 2016.

55. Jin G, Deng Y, Miao R, Hu Z, Zhou Y, Tan Y, Wang J, Hua Z, Ding W, Wang L, et al: TGFB1 and TGFBR2 functional polymorphisms and risk of esophageal squamous cell carcinoma: A case-control analysis in a Chinese population. J Cancer Res Clin Oncol 134: 345-351, 2008.

This work is licensed under a Creative Commons Attribution-NonCommercial-NoDerivatives 4.0 International (CC BY-NC-ND 4.0) License. 